\title{
Nutritional and Anti-Nutrient Composition of Three Kola Nuts (Cola nitida, Cola acuminata and Garcinia kola) Produced in Benin
}

\author{
Durand Dah-Nouvlessounon', Adolphe Adjanohoun², Haziz Sina1, Pacôme A. Noumavo1, \\ Nafan Diarrasouba ${ }^{3}$, Charles Parkouda ${ }^{4}$, Yann E. Madodé5, Mamoudou H. Dicko6, \\ Lamine Baba-Moussa ${ }^{*}$ \\ ${ }^{1}$ Laboratoire de Biologie et de Typage Moléculaire en Microbiologie, FAST, Université d'Abomey-Calavi, \\ Cotonou, Bénin \\ ${ }^{2}$ Centre de Recherches Agricoles Sud, Institut National des Recherches Agricoles du Bénin, Attogon, Bénin \\ ${ }^{3}$ UFR des Sciences Biologiques, Université Péléforo Gon Coulibaly, Korhogo, Côte d'Ivoire \\ ${ }^{4}$ Département de Technologie Alimentaire, IRSAT/CNRST, DTA, Ouagadougou, Burkina Faso \\ ${ }^{5}$ Département de Nutrition et Sciences Alimentaires, FSA, Université d'Abomey-Calavi, Cotonou, Bénin \\ ${ }^{6}$ Laboratoire de Biochimie Alimentaire, Enzymologie, Biotechnologie Industrielle et Bioinformatique, Université \\ de Ouagadougou, Ouagadougou, Burkina Faso \\ Email: "laminesaid@yahoo.fr
}

Received 16 October 2015; accepted 17 November 2015; published 20 November 2015

Copyright @ 2015 by authors and Scientific Research Publishing Inc.

This work is licensed under the Creative Commons Attribution International License (CC BY).

http://creativecommons.org/licenses/by/4.0/

(c) (i) Open Access

\section{Abstract}

Kola nuts were regularly chewed by West Africans and Beninese in particularly. The aim of this study was to investigate nutritional and anti-nutrient content of three Benin's kola nuts (Cola nitida, Cola acuminata and Garcinia kola). Proximate composition of the three species of kola nuts was assessed using standard analytical AOAC methods. Phenolics and flavonoids contents were determined by Folin-Ciocalteu and aluminum trichloride methods, respectively. Mineral composition was determined by Atomic Absorption Spectrometry method. Free and total amino acids were separated and quantified by HPLC. Protein content of the three kola nuts ranges from $4.95 \%$ ( $G$. kola) to $10.64 \%$ (C. acuminata) whereas fat content ranges from $0.2 \pm 0.00$ (C. nitida) to $2.5 \pm 0.42$ (G. kola). Total phenolics abounded $(2444.96 \pm 81.56 \mu \mathrm{g} \mathrm{Eq} \mathrm{AG/100g)} \mathrm{in} \mathrm{C.} \mathrm{acuminata,} \mathrm{while} \mathrm{fla-}$ vonoids predominated $(561.69 \pm 22.10 \mu \mathrm{gEqQ} / 100 \mathrm{~g})$ in $G$. kola. The three species are a good source of magnesium and a copper provider was lowest in $C$. nitida $(0.59 \pm 0.08 \mathrm{mg} / \mathrm{g})$ and in $C$. acuminata $(0.65 \pm 0.02 \mathrm{mg} / \mathrm{g})$. The dominant total essential amino acids were threonine $(C$. acu-

"Corresponding author.

How to cite this paper: Dah-Nouvlessounon, D., Adjanohoun, A., Sina, H., Noumavo, P.A., Diarrasouba, N., Parkouda, C., Madodé, Y.E., Dicko, M.H. and Baba-Moussa, L. (2015) Nutritional and Anti-Nutrient Composition of Three Kola Nuts (Cola nitida, Cola acuminata and Garcinia kola) Produced in Benin. Food and Nutrition Sciences, 6, 1395-1407.

http://dx.doi.org/10.4236/fns.2015.615145 
minata) and methionine ( $C$. acuminata and G. kola), while the predominant non-essential total amino acids according to species were arginine $(C$. nitida and $G$. kola), proline $(C$. acuminata) and cysteine $(G$. kola). For the anti-nutrients factors, saponins were in great proportion $(8.33 \% \pm$ $0.25 \%)$, while the oxalates were in small proportion $(0.44 \% \pm 0.04 \%)$. The three species have an interesting nutritional composition, but these seeds have the relatively lowest amino acids content.

\section{Keywords}

Kola Nuts, Polyphenolic Compound, Micronutrient, Benin

\section{Introduction}

Plants are important in human being everyday existence. They provide our foods, produce the oxygen that we breathe, and use as raw materials for many industrial products such as clothes, foot wears and so many others. Plants also provide raw materials for our buildings and in the manufacture of dyes, perfumes, pesticides and drugs [1]. These plants contain the wild fruits currently used for their fruits, seeds, kernels, flowers, sap and other edible products. Indeed, these elements are important in diets food and could powerfully help to solve or minimize the problems of food insecurity [2] [3]. Wild fruits are an important (quality and quantity) part of the diet, especially for children [4]. Some wild fruits also can be kept for $4-5$ months during the dry season [5]. It is generally accepted that the concentration of vitamin $\mathrm{C}$ in the indigenous wild fruits is higher than that in exotic fruits [6]. The protein content of seeds and kernels of native species is high. The wild fruits are also good sources of carbohydrate, calcium, magnesium and potassium [7] [8].

Kola nut (Cola spp.) belongs to the Steruliacea plant family with over 20 species native to the Africa tropical rain forest [9]. Cola nitida and Cola acuminata are the most common Cola species used. These species are sources of caffeine in processing and pharmaceutical industries and often chewed by some ethnic's group settings as stimulants [10]. The presence of other chemicals in kola nuts such as kolanin and theobromine also makes them suitable for use in drug preparation [11]. In addition, research has shown some potential uses of kola nut in the production of wine, chocolate and many non-alcoholic beverages [12]. Apart of those two species cited above, there is Garcinia kola (angiospermae) belonging to the Clusiaceae family [13]. The seeds of G. ko$l a$ are currently used in traditional medicine in many herbal formulations and have potential therapeutic benefits due largely to the activity of their flavonoids and other bioactive compounds [14]-[16].

In Benin the nuts of these three species are regularly chewed and have varied socio-cultural importance. Unfortunately, in the country, very few scientific studies have been carried out on those species [17]. Apart of the biochemical characterization and the nutritional properties of seeds, it is important to investigate the anti-nutrienal factors [18]. Indeed, the anti-nutritional factors have been described as substances that block or inhibit important metabolic pathways, especially digestion [19]. These substances are known to reduce the bioavailability of many nutrients such as proteins, vitamins and minerals. For example, minerals and trace elements are inefficiently and variably absorbed from diet due to many factors including anti-nutrients such as phytates, oxalates, tannins, and cyanides in foods [20]. Against this background the following questions are raised: 1) what is the composition of nutritional compounds of studying Benin's kola nuts? 2) What is the anti-nutritional profile of these three species nuts? In this direction, the essence of this research is to examine the proximate, nutritional and anti-nutrient composition of three species of kola nut collected in Benin.

\section{Material and Methods}

\subsection{Collection and Sample Preparation}

Fresh nuts of three plants (C. nitida, C. acuminata and G. kola) were collected in the village of Adjarra $\left(6^{\circ} 24^{\prime} 0^{\prime \prime} \mathrm{N}, 2^{\circ} 12^{\prime} 0^{\prime \prime} \mathrm{E}\right)$, Oueme region, Benin. The red variety of $C$. nitida and C. acuminata, were collected. After collection, the nuts were identified at Benin National Herbarium, University of Abomey-Calavi. Smooth kola powder (nuts dried $25^{\circ} \mathrm{C} \pm 2^{\circ} \mathrm{C}$ for 12 days and milled) as well as fresh nut were stored in airtight glassware and kept in darkness at $-20^{\circ} \mathrm{C}$ until use. 


\subsection{Nutritional Analysis}

\subsubsection{Proximate Analysis}

Standard methods of the Association of Official Analytical Chemists AOAC [21] were used to determine the moisture, crude fat, crude protein, crude fiber, total ash contents of the nuts. Moisture content was determined by desiccation of $5 \mathrm{~g}$ of sample to a constant weight at $105^{\circ} \mathrm{C}$ for 3 hours. Crude protein content was determined by Kjeldahl method using 6.25 as conversion constant. Crude fat content was assessed though Soxhlet method using petroleum ether as organic solvent. The total sugars were measured by spectrometry method [22] at 492 $\mathrm{nm}$ using D-glucose as standard. Reducing sugars were also measured by spectrometry method described by Miller [23] with a reagent 3.5 dinitrosalicylic acid (DNS) at $546 \mathrm{~nm}$ using maltose as standard.

\subsubsection{Determination of Total Phenolic Compound}

Total phenolics were quantified in extracts made from 1/15 sample (w:v) fresh nuts of each species once ground with mixer grinder using Folin-Ciocalteu's method described by Singleton [24] and adapted to 96 well-plate. At first it was revealed the extraction capacity of six solvents (water, water- $\mathrm{HCl} 1 \%$; ethanol; ethanol-HCl $1 \%$; methanol and methanol-HCl 1\%) with C. nitida. Twenty five microlitre of Folin-Ciocalteu's reagent (50\% v/v) was added to $10 \mu \mathrm{l}$ of $1 \mathrm{mg} / \mathrm{ml}(\mathrm{w} / \mathrm{v})$ of the nuts extract dissolved in solvents. After incubation $(5 \mathrm{mn})$ at room temperature, $25 \mu \mathrm{l}$ of $20 \%(\mathrm{w} / \mathrm{v})$ sodium carbonate $\left(\mathrm{Na}_{2} \mathrm{CO}_{3}\right)$ and water were added to a final volume of $200 \mu \mathrm{l}$ per well. Blanks were prepared by replacing the reagent by water to correct for interfering compounds. After incubation (30 min), the absorbence was read at $760 \mathrm{~nm}$ using a multiwell plate reader. All the assays were carried out at least in triplicate. Gallic acid $(0-500 \mu \mathrm{g} / \mathrm{ml})$ was used as standard and results were expressed as microgram gallic acid equivalent per 100 gram of extract. The solvent that extracts the number of compound was used to determine the total phenolic content of $C$. acuminata and G. kola following the same method described above.

\subsubsection{Determination of Total Flavonoïds Compound}

The total flavonoids of each sample were quantified by aluminum trichloride method described by Yi et al. [25] and adapted to 96 well-plates. Hundred microlitre of methanolic $\mathrm{AlCl}_{3}(2 \%)$ were mixed with $100 \mu \mathrm{l}$ of appropriate dilution of extracts solution. After incubation (15 min), the absorbence were read at $415 \mathrm{~nm}$ with a software "Gen5" using a multi plate Epoch spectrophotometer Biotech connected to a computer against a blank (mixture of $100 \mu \mathrm{l}$ methanolic extract solution and $100 \mu \mathrm{l}$ methanol) and compared to a quercetin $(0-50 \mu \mathrm{g} / \mathrm{ml})$ calibration curve $\left(\mathrm{R}^{2}=0.99\right)$. The flavonoid content was expressed as microgram of quercetin equivalents per $100 \mathrm{~g}$ of extract.

\subsubsection{Determination of Micro-Nutriments}

The mineral contents (Zn, Mg, Ca, $\mathrm{Cu}$ and $\mathrm{Fe}$ ) of each sample were determined by Atomic Absorption spectrometry after dry ashing of the samples according to method describe by Pinta et al. [26]. Vitamin C was determined by colorimetrie method with 2,6-dichlorophénolindophénol (DIP). For Amino acid profile, separation and quantification of free and total amino acids was accomplished by High Performance Liquid Chromatography (HPLC) with PICO·TAG method described by Bildlingmeyer et al. [27]. After drying, redrying, hydrolysis and derivatization, $100 \mu \mathrm{l}$ syringes is used to inject $40 \mu \mathrm{l}$ samples into the HPLC injector equipped of waters in + line-degaser AF 600 controller and dual $\lambda$ absorbance detector waters 2487 id.nr.13300261. Four microlitre of injection volume is analyzed.

\subsection{Anti-Nutritional Factors Analysis}

Tannin content was determined by spectrometry method as described by Sombié et al. [28]. The results were expressed as milligramme of tannic acid equivalents (TAE) per $100 \mathrm{mg}$ of extract (mg TAE/100mg extracts). The content of saponins was determined according to Sathya et al. [29] method. The gravimetric method previously described by Mir et al. [30] was used in the determination of kola nuts total alkaloid contents. Phytic acid was determined according with Lucas and Markakas [31] procedure.

\section{Results and Discussion}

\subsection{Proximate Analysis}

The proximate composition of the three species of kola nut is shown in Table 1. 
Table 1. Proximate composition of different species of kola nut.

\begin{tabular}{cccc}
\hline Parameter (\% DM) & \multicolumn{3}{c}{ Content (Mean \pm SD) } \\
Moisture & C. nitida & C. acuminata & G. kola \\
\cline { 2 - 4 } Dry matter (DM) \% & $12.46 \pm 0.80$ & $10.20 \pm 0.80$ & $8.46 \pm 0.83$ \\
Total ash & $87.53 \pm 0.80$ & $89.80 \pm 0.80$ & $91.53 \pm 0.83$ \\
Fat & $3.00 \pm 0.50$ & $3.50 \pm 0.86$ & $2.00 \pm 0.50$ \\
Protein & $0.20 \pm 0.00$ & $1.20 \pm 0.28$ & $2.50 \pm 0.42$ \\
Total sugars (TS) & $10.06 \pm 0.75$ & $10.64 \pm 0.50$ & $4.95 \pm 0.25$ \\
Reducing sugars (\% TS) & $5.18 \pm 0.56$ & $5.57 \pm 0.12$ & $6.27 \pm 0.61$ \\
Energizing value (Kcal·g ${ }^{-1}$ ) & $8.30 \pm 0.78$ & $15.22 \pm 0.34$ & $93.49 \pm 0.36$ \\
Crude fibre & $85.58 \pm 0.12$ & $98.98 \pm 0.57$ & $1.35 \pm 0.12$ \\
\hline
\end{tabular}

\section{Moisture}

The moisture content of the three species ranged between 8.46 - 12.46, with $C$. nitida having the highest (12.46 \pm 0.80$)$ moisture content and $G$. kola the least $(8.46 \pm 0.83)$. The values obtained are on the one hand below those found by Ajai et al. [32], which are between $20.62-22.50$ for the three species, as well as those found by Odebumi et al. [33] for C. nitida $(66.40 \pm 0.08)$ and $G$. kola $(60.48 \pm 0.06)$. On the over hand, these values are above those obtained by Dewole et al. [18] which obtained $9.73 \pm 0.02$ for C. acuminata and $9.81 \pm 0.01$ for $C$. nitida and $7.2 \pm 0.08$ for G. kola [1]. This variation of moisture content in the different studies would be related to drying time of the samples before analysis because Lowor et al. [34] showed in their study that the moisture content of a sample varies by drying time of the latter. The high moisture content is an index of spoilage. Too much of moisture in any food sample can make the sample viable for microorganisms growth. This accounts for most of the biochemical and physiological reactions in the plant [35]. Indeed, the low moisture content of the three species of kola nuts is good for their long preservation as it will prevent early spoilage of the nuts. It is like this beneficial to the buyers of three species of kola as most sellers sell by volume and not by weight [36].

Protein

Protein content of the three species ranges from, 4.95 (G. kola) to $10.64 \%$ (C. acuminata) but the content of C. nitida $(10.06 \% \pm 0.75 \%)$ is near of those obtains with $C$. acuminata. Other researches were also showed the proximity between $C$. nitida and $C$. acuminata protein content. For the both species, our results were on the one hand higher of those obtained by Arogba [37] with C. nitida (3.5\%) and Ajai et al. [32] in Niger which obtained $8.68 \%$ for $C$. nitida and 8.65 for C. acuminata. On the other hand, the results of this study were lower than those obtain Adeyeye et al. [36] concerning C. acuminata (11.95\%) and also those obtained by Dewole et al. [18] in Nigeria which obtained $15.24 \% \pm 0.58 \%$ with $C$. nitida and $19.14 \% \pm 0.25 \%$ with C. acuminata. The difference between these studies may be due to pedology and ecological conditions because the water deficit influences the nitrogen supply in the plant [38]. Moreover physiological characteristics of a plant which confers a greater resistance to the nitrogen supply to water deficit are also genetically variable [39]. The protein content relatively high could complement the body's need of these essential nutrients for growth and development because proteins, another class of food often times referred to as the "Nitrogen-containing natural product", has been proved to be essential for the survival of human beings and animals [40]. Likewise concerning G. kola, we note that our data were higher than those of Adesuyi et al. [1] which obtained 1.85\% $\pm 0.15 \%$. On the contrary Ajai et al. [32] were obtained in their study the content twice higher than ours.

\section{Fat and Ash}

G. kola presents the higher content (2.5\% $\pm 0.42 \%)$ in fat while C. nitida have the lowest $(0.2 \% \pm 0.00 \%)$. For C. nitida, this result can be comparable to $0.87 \%$ obtains by [32] Ajai et al. (2012). Contrary to our study, Odebunmi et al. [33] have showed that the fat content of G. kola seeds (4.51\% $\pm 0.56 \%)$ was low to those obtained with $C$. nitida $(5.71 \% \pm 0.74 \%)$. The low lipid content of these nuts is predictable because these seeds are not oleaginous. For the three species, the ash content is higher than which obtained by Dewole et al. [18], but the 
comparable results were obtained by Ajai et al. [32], Agbeniyi and Ayodele [41] and Adeyeye and Ayejuyo [36] for C. acuminata.

\section{Carbohydrates and Energy Content}

Among the three species, G. kola has high content of total sugar $(6.27 \% \pm 0.61 \%)$ and also has the lowest content of reducing sugar $(6.48 \% \pm 0.36 \%)$. $C$. nitida and $C$. acuminata have similar total sugar content while $C$. acuminata has highest content of reducing sugar (15.22\% $\pm 0.34 \%)$. Agbeniyi and Ayodele [41] reported in their study high content of carbohydrate. Furthermore, the results show that G. kola has the highest energy value $(93.49 \pm 0.17 \mathrm{Kcal} / \mathrm{g})$ while $C$. nitida has the lowest $(85.58 \pm 0.12 \mathrm{Kcal} / \mathrm{g})$.

The varying composition reported by different authors may imply that the proximate composition of these nuts varies with season, environment and/or condition or time of evaluation.

\subsection{Polyphenolic and Flavonoïds Content}

Figure 1 presents the solvent ability to total phenolic compound extraction.

The best phenolics compound extraction solvent is mixture methanol 1\% chlorydric acid. From the starting three solvents (water, ethanol and methanol), the extraction of the phenolic compounds is important when the dipole moment of the solvent is low. The extraction was done therefore according to the polarity of involved solvents. Furthermore, chlorhydric acid addition seems not define the same extraction pattern, but rather revealed a beneficial synergistic effect of extraction ability of each solvent with chlorhydric acid. This effect will vary depending on the solvent and is more beneficial to methanol. Similar results were obtained by Dicko et al. [42] on Sorghum bicolor.

Table 2 shows the kola nuts total polyphenolic content determined with methanol chlorydric acid (1\%) and flavonoids content of three species.

The three species have a high content of total phenolic compound but which varies according to the plant species. C. acuminata has a high concentration while $C$. nitida presents a low concentration. Since the three species are regularly chewed, these results are interesting because phenolics can play an important role in adsorbing and neutralizing free radicals, quenching oxygen, or decomposing peroxides. It has been suggested to exert beneficial pharmacological effects on neurological disorders on the basis of in vitro observations [43] [44]. Polyphe-

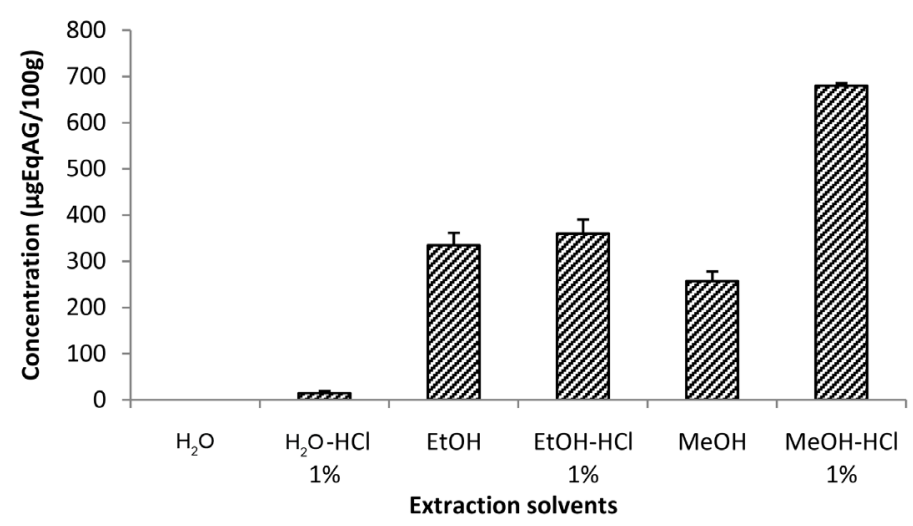

Figure 1. Variation of C. nitida total phenolics compound according to different solvents. $\mathrm{H}_{2} \mathrm{O}$ : Water; HCl: Chlorydric acid; EtOH: Ethnol; MeOH: Methanol.

Table 2. Polyphenolic and flavonoïds content of three species of kola nut.

\begin{tabular}{ccc}
\hline \multirow{2}{*}{ Plant species } & \multicolumn{2}{c}{ Parameters } \\
\cline { 2 - 3 } C. nitida & Total phenolic $(\mu \mathrm{gEqAG} / 100 \mathrm{~g})$ & Total flavonoïds $(\mu \mathrm{gEqQ} / 100 \mathrm{~g})$ \\
\hline C. acuminata & $679.87 \pm 5.22$ & $374.60 \pm 80.75$ \\
G. kola & $2444.96 \pm 81.56$ & $537.38 \pm 92.99$ \\
\hline
\end{tabular}


nolic compounds in plant, exert anti carcinogenic, anti mutagenic and cardio protective effects linked to their free radical scavenging [44] [45]. It has been reported that to be chemopreventive agents by lowering cholesterol and roughly limit cell damage [46]. G. kola has the highest total flavonoids content (561.69 $\pm 22.10 \mu \mathrm{gEqQ} /$ $100 \mathrm{~g})$. These results show that the total flavonoids represent a large portion in G. kola total phenolics composition. Terashima et al. [47] and Adesuyi et al. [1] reported also that G. kola can be a good dietary source of flavonoids. Indeed, among the three kola nuts, the consumption of $G$. kola nut would be more advantageous than those of $C$. nitida and C. acuminata because, flavonoids which are generally found in a variety of foods, such as oranges, tangerines, berries, apples and onions have protective effects including anti inflammatory, anti-oxidant, antiviral, and anti carcinogenic properties [48].

\subsection{Micronutrient Content}

The mineral and vitamin C composition of kola nut is shown in Table 3.

The mineral content in the three species of kola nut varied according to species. Calcium (Ca) value ranged between $1.33-4.3 \mathrm{mg} / \mathrm{g}$ and C. nitida had the highest concentration. C. acuminata and G. kola had the similarly value. However calcium content have not inconsiderable because the level is relatively high compared to the level reported for African Adansonia digitata kernel (0.43 - $3.76 \mathrm{mg} / 100 \mathrm{~g})$ by Ajayi et al. [49] and Nnam and Obiakor [8]. These elements support human biochemical processes by serving structural and functional roles as electrolytes [50].

The zinc ( $\mathrm{Zn}$ ) content is relatively low for the three species, but $C$. acuminata present the highest concentration $(1.36 \pm 0.27 \mathrm{mg} / \mathrm{g})$. Despite the relatively lowest concentration of Zinc, his presence in these nuts is important because zinc has been associated with enzyme systems, particularly oxidation processes [36]. It has a structural and functional role in a large number of macromolecules and is required for over 300 enzymic reactions. Zinc ions $\left(\mathrm{Zn}^{2+}\right)$ participate in all aspects of intermediary metabolism, transmission, and regulation of the expression of genetic information, storage, synthesis, and action of peptide hormones and structural maintenance of chromatin and biomembranes [51]. It is estimated that up to $1 \%$ of the human genome codes for zinc finger proteins. In the central nervous system, zinc has an additional role as a neurosecretory product or cofactor [52].

Among the three species, the results shown that $C$. nitida present the highest concentration of iron (4.37 \pm $0.53 \mathrm{mg} / \mathrm{g})$ while $G$. kola displayed the lowest $(1.37 \pm 0.17 \mathrm{mg} / \mathrm{g})$. These values differ from earlier reports in other works [53] [41]. The presence in these nuts of this element is good because iron plays an important role for human health [54]. The body requires iron for the synthesis of oxygen transport proteins, in particular hemoglobin and myoglobin, and for the formation of enzymes involved in electron transfer [55].

Magnesium is the most abundant mineral element in the three kola nuts. The similarly trend was observed by Agbeniyi and Ayodele [41] and Odebunmi et al. [33] in relation to the studied mineral elements. The magnesium values ranged from $10 \pm 0.23 \mathrm{mg} / \mathrm{g}$ (C. acuminata) to $11.48 \pm 0.05 \mathrm{mg} / \mathrm{g}$ (C. nitida). This account observed in the kola nuts is interesting because, Magnesium is used now, as adjunct to tocolytic therapy, or alone, to prevent premature uterine contractions and preterm births [56]. In addition, magnesium is essential, especially within cells, being the second most common intracellular cation after potassium, with both these elements being vital for numerous physiological functions [57].

Table 3. Micronutrient composition of three species of kola nuts

\begin{tabular}{|c|c|c|c|}
\hline \multirow{2}{*}{ Elements } & \multicolumn{3}{|c|}{ Sample value mg/g (Mean \pm SD) } \\
\hline & C. nitida & C. acuminata & G. kola \\
\hline $\mathrm{Ca}$ & $4.33 \pm 1.41$ & $1.66 \pm 0.47$ & $1.33 \pm 0.00$ \\
\hline $\mathrm{Zn}$ & $0.69 \pm 0.19$ & $1.36 \pm 0.27$ & $0.39 \pm 0.15$ \\
\hline $\mathrm{Fe}$ & $4.37 \pm 0.53$ & $2.75 \pm 0.35$ & $1.37 \pm 0.17$ \\
\hline $\mathrm{Mg}$ & $11.48 \pm 0.05$ & $10.00 \pm 0.23$ & $10.73 \pm 0.66$ \\
\hline $\mathrm{Cu}$ & $0.59 \pm 0.08$ & $0.65 \pm 0.02$ & $1.47 \pm 0.35$ \\
\hline Vit C (mg/100ml) & $6.26 \pm 0.46$ & $0.53 \pm 0.61$ & $1.20 \pm 0.61$ \\
\hline
\end{tabular}


The cooper content in the three kola nuts decreases as follows G. kola $>$ C. acuminata $>$ C. nitida. Whereas $C$. nitida present the highest value of Vit $C(6.26 \pm 0.46 \mathrm{mg} / 100 \mathrm{ml})$ what is not negligible. The vitamin $C$ protects organism against the free radicals because it is the most effective antioxydant. It takes part in several metabolic processes, like the biosynthesis of collagen in conjunctive, and as neurotransmettor. Vit $C$ increases the absorption of calcium and the biodisponibility of iron and is link to the prevention of many degenerative diseases [58].

\subsection{Amino Acids Content}

Figure 2 shows the auto-scaled chromatogram profile of standard, total and free amino acids while Table 4 shows their amount.

The results show that $52.94 \%$ (9/17) of amino acids search was obtained in the kola nuts. The total amino acids were more measure than free. In addition, $66.66 \%$ of these free amino acids measured were non-essential. For total amino acids, the dominant essential amino acids are threonine (C. acuminata) and methionine (C. acuminata and G. kola), while the predominant non-essential amino acids according to species are arginine (C. nitida and G. kola), and proline (C. acuminata). Beside threonine and lysine are the free essential amino acids measured, therefore the amino acids content varied according to the species. Indeed, $100 \%$ of total amino acids measured are present in C. nitida against $90 \%$ in C. acuminata and $77.77 \%$ in G. kola. Whereas proline is the free amino acids more concentred in the three Cola species but the highest concentration $(0.69 \pm 0.06 \mathrm{w} / \mathrm{w} \%$ dry weight) is obtained with $C$. nitida while $C$. acuminata and $G$. kola displays the lowest $(0.61 \pm 0.01 \mathrm{w} / \mathrm{w} \%$ dry weight). However the three species have not great amino acids content, Eleyinmi et al. [59] were reports the relatively low concentrations of amino acids while Adeyeye et al. [60] report the high concentration of amino acids. The difference of results could be explained by the nuts pretreatment before analysis.

\subsection{Quantitative Anti-Nutrient Screening of Kola Nut}

The Table 5 shows the anti-nutrient content of three kola nuts. The result shows that $C$. acuminata has high value $(8.33 \% \pm 0.25 \%)$ of these nuts anti-nutrient (saponin) content while $C$. nitida has the lowest $(0.44 \% \pm$ $0.04 \%)$ with the oxalates.

Table 4. Total and free amino acids concentration of three species of kola nut w/w\% (dry weight).

\begin{tabular}{|c|c|c|c|c|c|c|}
\hline \multirow{2}{*}{ Amino acids } & \multicolumn{2}{|c|}{ C. nitida } & \multicolumn{2}{|c|}{ C. acuminata } & \multicolumn{2}{|c|}{ G. kola } \\
\hline & Total & Free & Total & Free & Total & Free \\
\hline Aspartic acid & $0.53 \pm 0.28$ & $0.53 \pm 0.28$ & - & - & - & - \\
\hline Arginine & $1.06 \pm 0.06$ & $0.69 \pm 0.06$ & $0.86 \pm 0.01$ & $0.61 \pm 0.01$ & $0.61 \pm 0.02$ & $0.61 \pm 0.02$ \\
\hline Threonine & $0.39 \pm 0.01$ & - & $0.33 \pm 0.04$ & - & - & - \\
\hline Alanine & $0.50 \pm 0.01$ & $0.20 \pm 0.01$ & $0.42 \pm 0.09$ & $0.23 \pm 0.07$ & $0.28 \pm 0.12$ & $0.19 \pm 0.00$ \\
\hline Proline & $0.83 \pm 0.04$ & $0.53 \pm 0.04$ & $1.83 \pm 0.23$ & $1.37 \pm 0.23$ & $0.10 \pm 0.13$ & - \\
\hline Valine ${ }^{*}$ & $0.35 \pm 0.01$ & - & $0.30 \pm 0.02$ & - & $0.33 \pm 0.08$ & - \\
\hline Methionine $^{*}$ & $0.22 \pm 0.00$ & - & $0.48 \pm 0.03$ & - & $0.43 \pm 0.26$ & - \\
\hline Cysteine & $0.27 \pm 0.00$ & - & $0.34 \pm 0.01$ & - & $0.19 \pm 0.27$ & - \\
\hline Lysine ${ }^{*}$ & $0.30 \pm 0.02$ & $0.16 \pm 0.02$ & $0.30 \pm 0.01$ & $0.16 \pm 0.00$ & $0.31 \pm 0.01$ & $0.18 \pm 0.13$ \\
\hline
\end{tabular}

With $^{*}$ : Essential amino acids; Without ${ }^{*}$ Non essential amino acids.

Table 5. Anti-nutrient composition of different species of kola nut.

\begin{tabular}{|c|c|c|c|}
\hline \multirow{2}{*}{ Parameters } & \multicolumn{3}{|c|}{ Kola nuts content (Mean \pm SD) } \\
\hline & C. nitida & C. acuminata & G. kola \\
\hline Alkaloids (\%) & $2.06 \pm 1.50$ & $1.80 \pm 0.52$ & $4.66 \pm 1.15$ \\
\hline Saponin (\%) & $4.66 \pm 0.03$ & $8.33 \pm 0.25$ & $5.83 \pm 0.01$ \\
\hline Oxalates (\%) & $0.44 \pm 0.04$ & $0.71 \pm 0.03$ & $0.74 \pm 0.02$ \\
\hline Phytic acid (\%) & $0.87 \pm 0.07$ & $0.60 \pm 0.01$ & $1.09 \pm 0.10$ \\
\hline Tanin (mg TAE/100mg) & $5.66 \pm 1.02$ & $7.08 \pm 0.11$ & $3.54 \pm 0.21$ \\
\hline
\end{tabular}




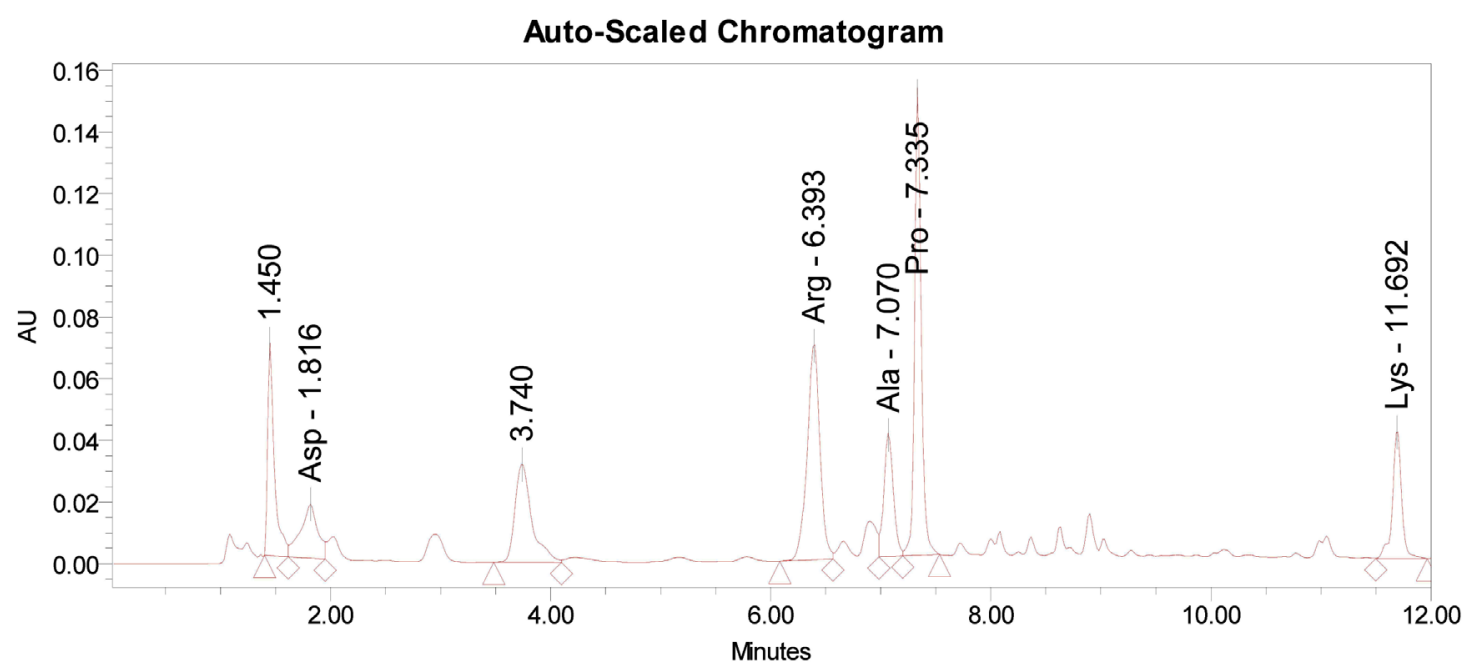

(a)

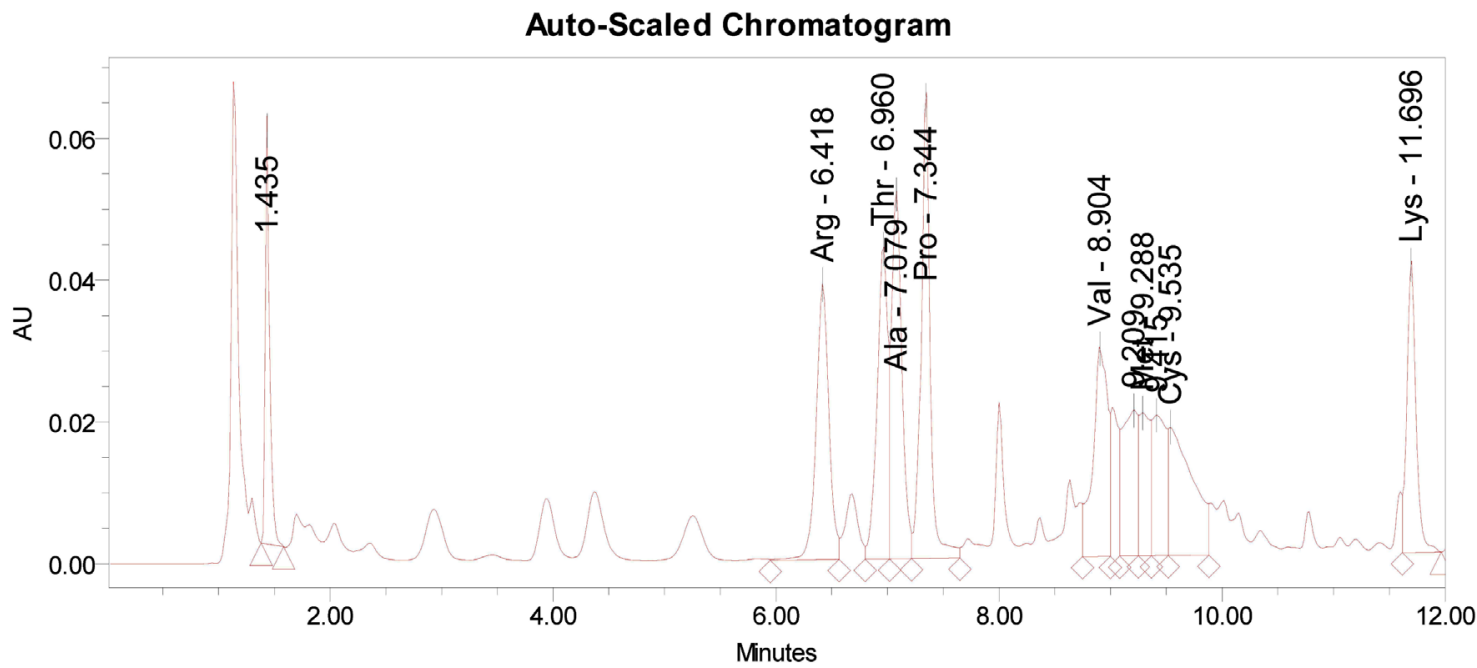

(b)

Auto-Scaled Chromatogram

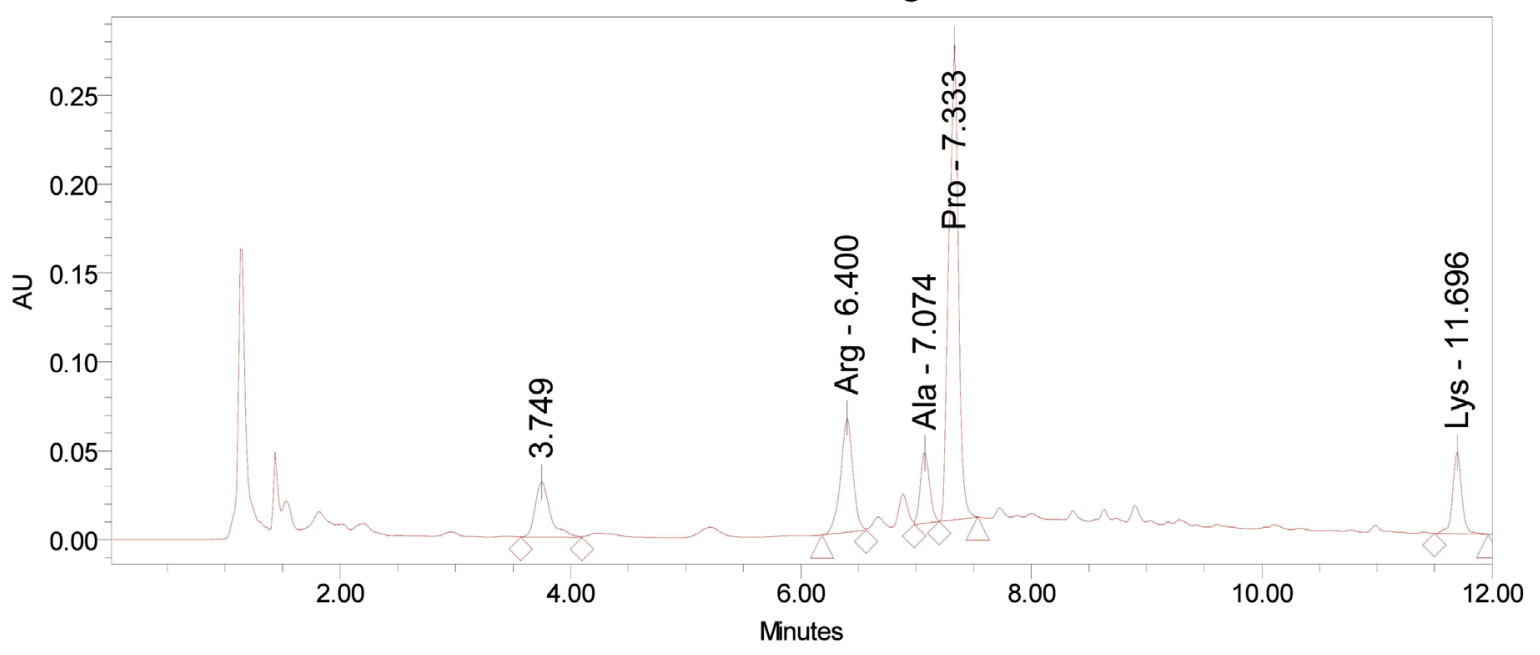

(c) 


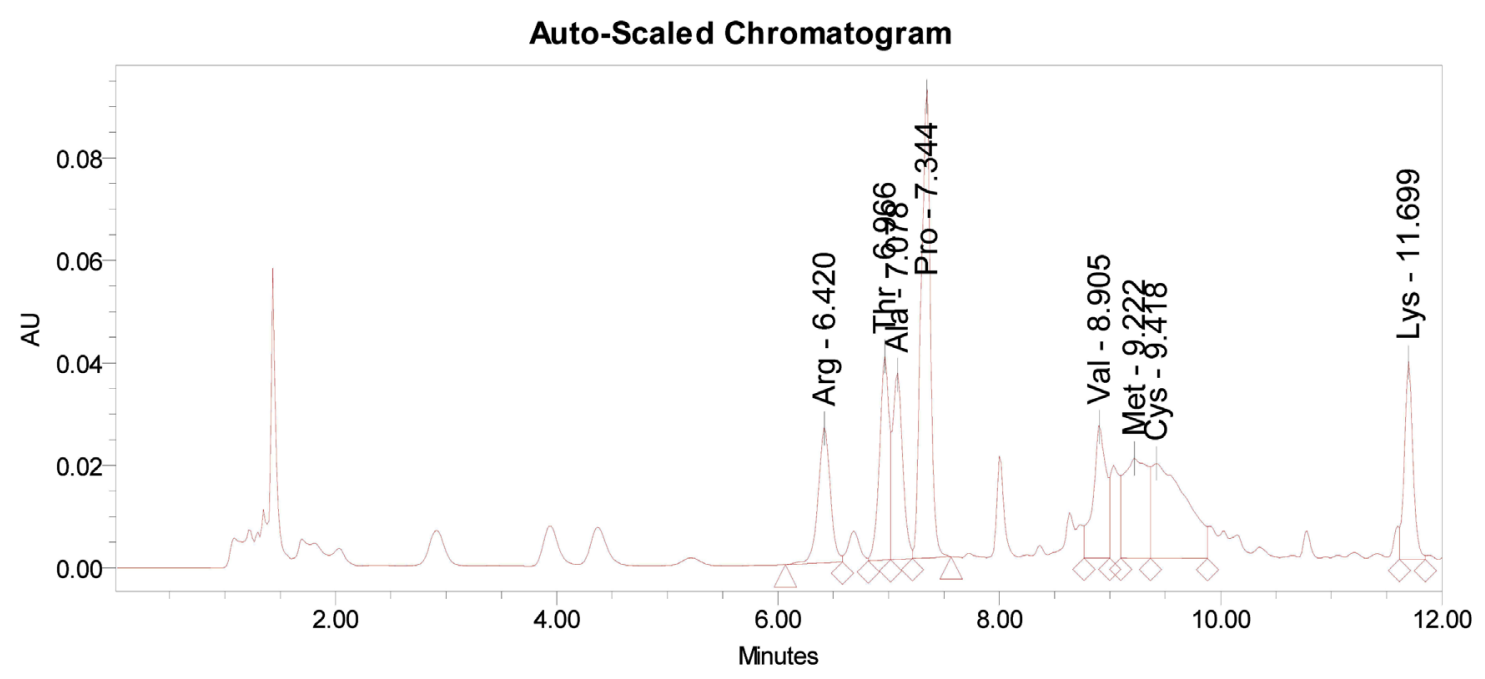

(d)

Auto-Scaled Chromatogram

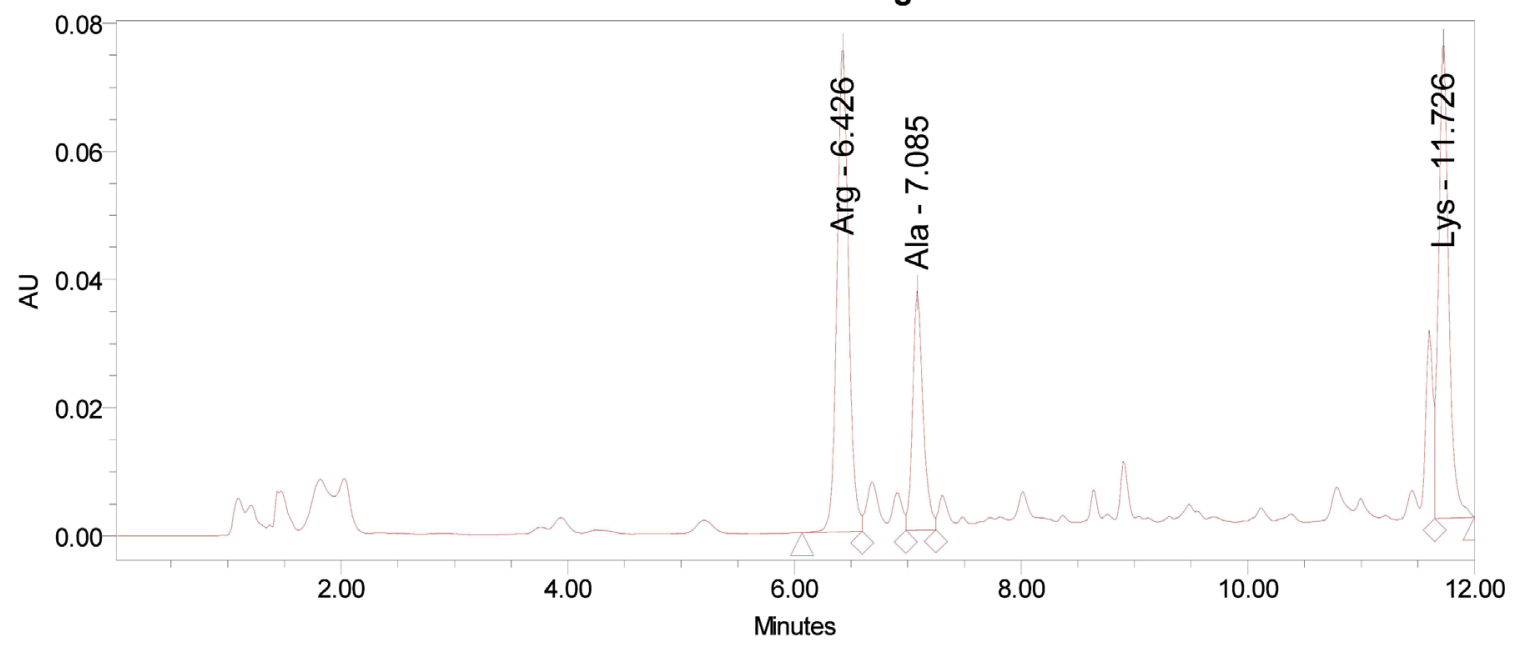

(e)

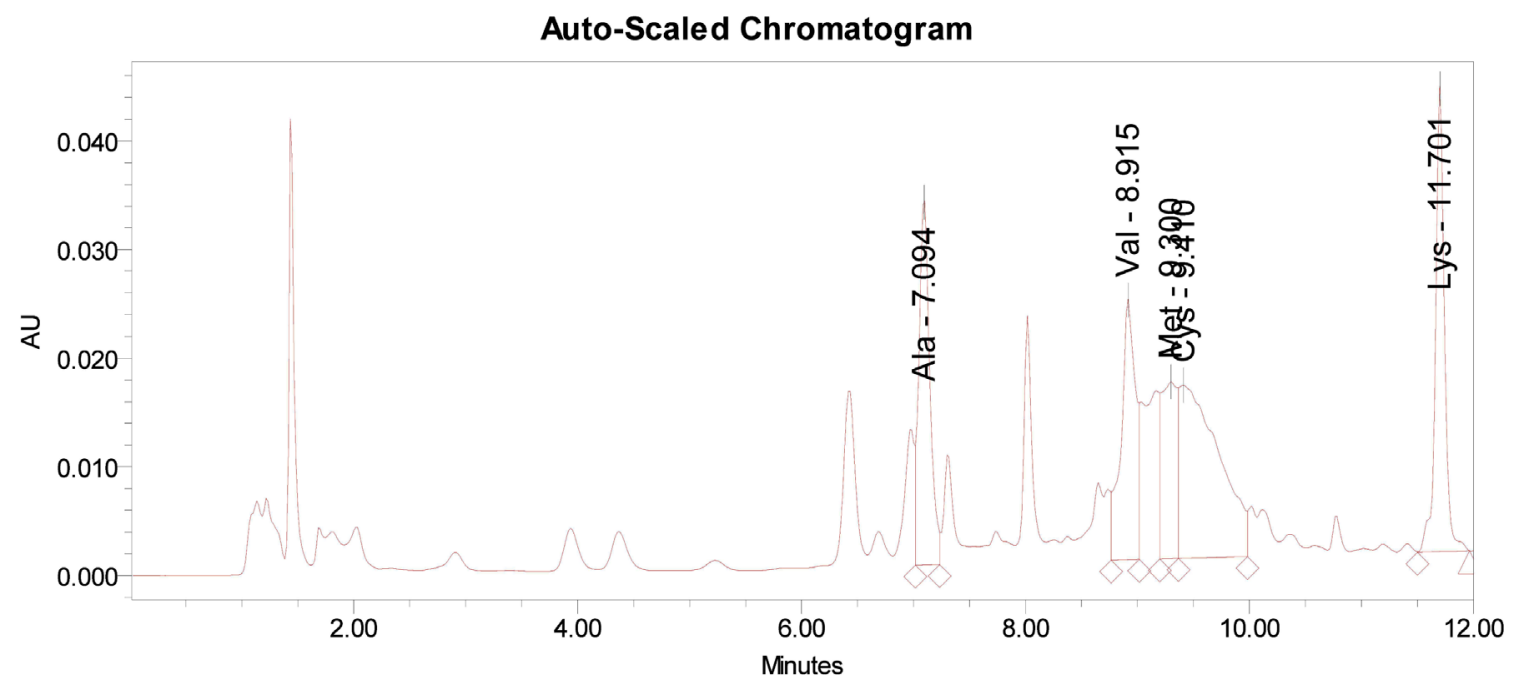

(f) 


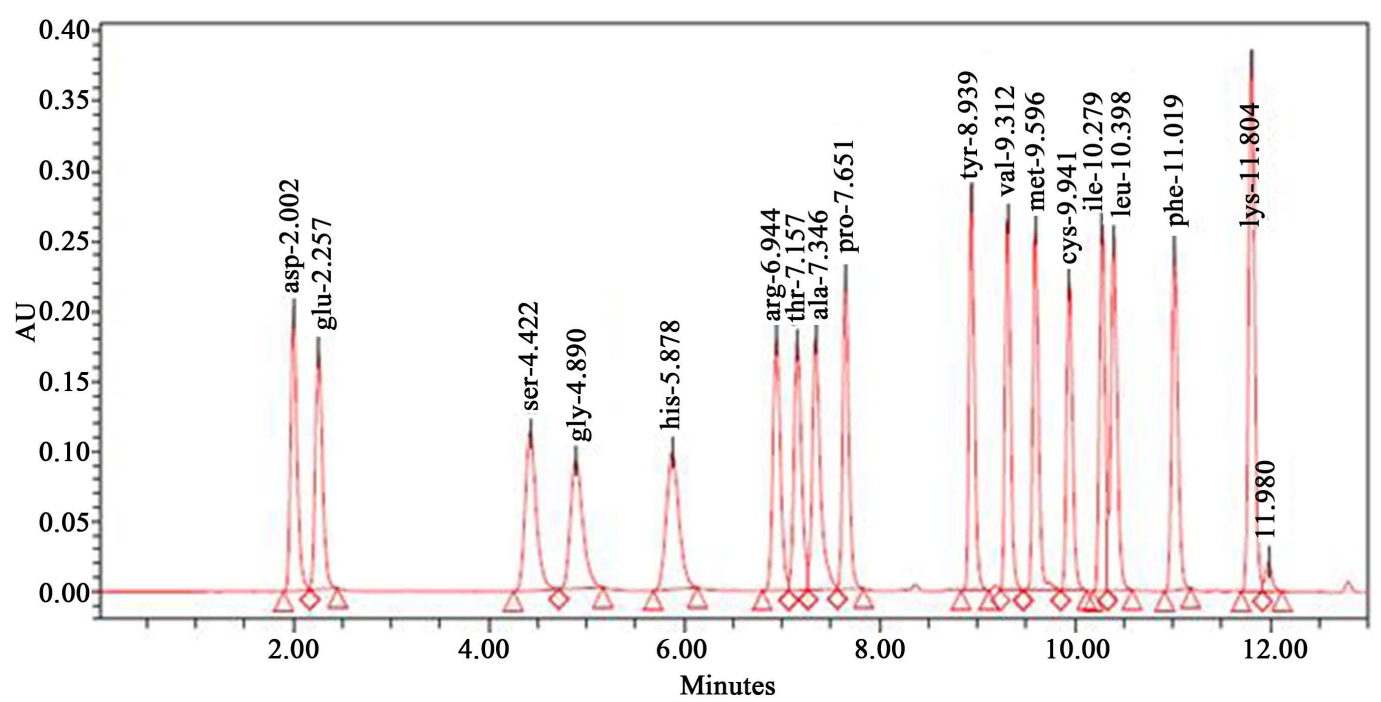

(g)

Figure 2. Total, free and standard amino acids auto-scaled chromatogram profile. (a) C. nitida free amino acids; (b) C. nitida total amino acids; (c) C. acuminata free amino acids; (d) C. acuminata total amino acids; (e) G. kola free amino acids; (f) G. kola total amino acids; (g) Pierce H Standard.

The high value of saponin was foreseeable with the three species because these compounds are glycosides containing a polycyclic aglycone moiety either $\mathrm{C}_{27}$ steroid or $\mathrm{C}_{30}$ triterrpenoid attached to carbohydrate and are characterised by a bitter taste and foaming properties [61]. The anti-nutritional effects of saponins have been mainly studied using alfalfa saponins [62]. They also cause haemolysis of red blood cells [63], and have been demonstrated to have anti-spermal effects on human spermatozoa [64]. Specifically G. kola has the high content of alkaloids $(4.66 \% \pm 1.15 \%)$ and phytic acid $(1.09 \% \pm 0.10 \%)$ than those of the two other species. Similarly, among the three kola nuts, $C$. acuminata shows the highest value of tannin (7.08 $\pm 0.11 \mathrm{mg}$ TAE/100mg). Tannins are water soluble phenolic compounds with reported antinutritional effects and may be by their ability to form complex with proteins. Indeed, tannins may form a less digestible complex with dietary proteins and may bind and inhibit the endogenous protein, such as digestive enzymes [65]. Besides, in ruminants, dietary condensed tannins ( $2 \%$ - 3\%) have been shown to impart beneficial effects because they reduce the wasteful protein degradation in the rumen by the formation of a protein-tannin complex [66]. The low value of oxalates and phytic acid in the three species was good because oxalates and phytates bind minerals like calcium and magnesium and interfere with their metabolism to cause muscular weakness and paralysis [67].

\section{Conclusion}

At the end of this study, it appears that the three selected species of kola nuts present an interesting nutritional composition but it varied according to species. The lipid content of the three kola nuts is very low while the protein content is relatively high for $C$. nitida and $C$. acuminata. They also have a high energy value. Similarly, the mineral composition of the three species is useful with a high vitamin $C$ content of $C$. nitida nut in comparison to the two other species ( $G$. kola and C. acuminata). Besides, these three kola nuts contain small quantities of total and free amino acids. In the same way, anti-nutrients factors in these nuts were in low proportion. Thus the nuts of those three kola species can be a good alternative to increase the food security in low income countries.

\section{Acknowledgements}

The authors thank UEMOA for the financial support through the project LBTMM-PAES-UEMOA-2012.

\section{References}

[1] Adesuyi, A.O., Elumm, I.K., Adaramola, F.B. and Nwokocha, A.G.M. (2012) Nutritional and Phytochemical Screen- 
ing of Garcinia kola. Advance Journal of Food Science and Technology, 4, 9-14.

[2] Okigbo, B.N. (1977) Neglected Plants of Horticultural Importance in Traditional Farming Systems of Tropical Africa. Acta Horticulturae, 53, 131-150. http://dx.doi.org/10.17660/ActaHortic.1977.53.18

[3] Getahun, A. (1990) The Role of Wild Plants in the Native Diet in Ethiopia. Agroecosystem, 1, 45-56.

[4] Falconer, J. (1990) Hungry Season, Food from the Forest. FAO Unasylva, 41, 14-19

[5] Peters, C.R. (1987) Ricinodendron rautanenii (Euphorbiaceae): Zambezian Wild Food Plant for All Seasons. Economic Botany, 41, 494-502. http://dx.doi.org/10.1007/BF02908143

[6] Wehmeyer, A.S. (1966) The Nutrient Composition of Some Edible Wild Fruits found in the Transvaal. South African Medical Association, 40, 1102-1104.

[7] Lockett, C.T., Calvert, C.C. and Grivetti, L.E. (2000) Energy and Micronutrient Composition of Dietary and Medicinal Wild Plants Consumed during Drought. Study of Rural Fulani, Northeastern Nigeria. International Journal of Food Sciences and Nutrition, 51, 195-208. http://dx.doi.org/10.1080/09637480050029700

[8] Nnam, N.M. and Obiakor, P.N. (2003) Effect of Fermentation on the Nutrient and Antinutrient Composition of Baobab (Adansonia digitata) Seeds and Rice (Oryza sativa) Grains. Ecology of Food and Nutrition, 42, 265-277. http://dx.doi.org/10.1080/03670244.2003.9657684

[9] Ogutuga, D.B.A. (1975) Chemical Compositon and Potential Commercial Uses of Kolanut. Cola nitida, Vent (Schott and Endicher). Ghana Journal of Agricultural Science, 8, 121-125.

[10] Okoli, B.J., Abdullahi, K., Myina, O. and Iwu, G. (2012) Caffeine Content of Three Nigerian Cola. Journal of Emerging Trends in Engineering and Applied Sciences, 3, 830-833.

[11] Lowe, H.I.C., Watson, C.T., Badal, S., Peart, P., Toyang, N.J. and Bryant, J. (2014) Promising Efficacy of the Cola acuminata Plant: A Mini Review. Advances in Biological Chemistry, 4, 240-245. http://dx.doi.org/10.4236/abc.2014.44029

[12] Jarvis, G. (2002) The Rise and Fall of Cocaine Cola. http://www.lewrockwell.com/jarvis/jarvis17.html

[13] Akoegninou, A., Van Der Burg, W.J. and Van Der Maesen, L.J.G. (2006) Flore analytique du Bénin, Backhuys Publishers, Leiden, Netherlands, Wageningen University Papers 06.2.

[14] Farombi, E.O., Tahnteng, J.G., Agboola, A.O., Nwankwo, J.O. and Emerole, G.O. (2000) Chemoprevention of 2Acetylaminofluorene-Induced Hepatotoxicity and Lipid Peroxidation in Rats by Kolaviron-A Garcinia kola Seed Extract. Food and Chemical Toxicology, 38, 535-541. http://dx.doi.org/10.1016/S0278-6915(00)00039-9

[15] Pietta, P.G. (2000) Flavonoids as Antioxidants. Journal of Natural Products, 63, 1035-1042. http://dx.doi.org/10.1021/np9904509

[16] Okunji, C.O., Ware, T.A., Hicks, R.P., Iwu, M.M. and Skanchy, D.J. (2002) Capillary Electrophoresis Determination of Biflavanones from Garcinia kola in Three Traditional African Medicinal Formulations. Planta Medica, 68, 440-444. http://dx.doi.org/10.1055/s-2002-32091

[17] Dah-Nouvlessounon, D., Adoukonou-Sagbadja, H., Diarrassouba, N., Sina, H., Noumavo, P.A., Baba-Moussa, F., Adjanohoun, A., Gbenou, J.D. and Baba-Moussa L. (2015) Antimicrobial, Antioxidant, Cytotoxic Activities and Phytochemical Assessment of Cola acuminata Used in Benin. International Journal of Pharmacy and Pharmaceutical Sciences, 7, 1-8.

[18] Dewole, E.A., Dewumi, D.F.A., Alabi, J.Y.T. and Adegoke A. (2013) Proximate and Phytochemical of Cola nitida and Cola acuminata. Pakistan Journal of Biological Sciences, 16, 1593-1596.

[19] Theil, E.C., Burton, J.W. and Beard, J.L. (1997) A Sustainable Solution for Dietary Iron Deficiency through Plant Bio-Technology and Breeding to Increase Seed Ferritin Control. European Journal of Clinical Nutrition, 51, $28-31$.

[20] Kolawole, S.E. and Obueh, H.O. (2013) A Study of the Oxalate, Phytate and Cyanide Contents of Selected Nigerian Foods and Diet in Akwa Ibom and Cross River States of Nigeria. African Journal of Food Science and Technology, 4, 44-47.

[21] AOAC (1990) Official Methods of Analysis of Association of Official Analytical Chemist. In: Herwitz, W., Ed., Association of Official Analytical Chemistry, Washington DC, 125-126.

[22] Fox, J.D. and Robyt, J.F. (1991) Miniaturization of Three Carbohydrate Analyses Using a Microplate Reader. Analytical Biochemistry, 195, 93-96. http://dx.doi.org/10.1016/0003-2697(91)90300-I

[23] Miller, G.L. (1958) Use of Dinitrosalicylic Acid Reagent for Determination of Reducing Sugar. Analytical Biochemistry, 195, 93-96.

[24] Singleton, V.L., Orthofer, R. and Lamuela-Raventós, R.M. (1999) Analysis of Total Phenols and Other Oxidation Substrates and Antioxidants by Means of Folin-Ciocalteu Reagent. Methods in Enzymology, 299, 152-178. http://dx.doi.org/10.1016/S0076-6879(99)99017-1 
[25] Yi, Z.B., Yu, Y., Liang, Y.Z. and Zeng, B. (2007) In Vitro Antioxidant and Antimicrobial Activities of the Extract of Pericarpium Citri Reticulatae of a New Citrus Cultivar and Its Main Flavonoids. LWT-Food Science and Technology, 4, 597-603.

[26] Pinta, A.A. (1973) Méthodes de référence pour la détermination des éléments minéraux dans les végétaux. Oléagineux, ORSTOM, Bondy, France.

[27] Bildlingmeyer, B.A., Cohen, S.A. and Tarvin, T.L. (1984) Rapid Analysis of Amino Acids Using Pre-Column Derivatization. Journal of Chromatography, 336, 93-104. http://dx.doi.org/10.1016/S0378-4347(00)85133-6

[28] Sombié, P.A.E.D., Hilou, A., Coulibaly, A.Y., Tibiri, A., Kiendrebeogo, M. and Nacoulma. O.G. (2011) Brain Protective and Erythrocytes Hemolysis Inhibition Potentials from Galls of Guiera senegalensis J.F. Gmel (Combretaceae). Journal of Pharmacology and Toxicology, 6, 361-370. http://dx.doi.org/10.3923/jpt.2011.361.370

[29] Sathya, V., Bharathidasan, R., Tamil, S., Selvi, N. Rebeccal, S., Ilakkiya, R. and Prabakaran, M. (2013) Quantitative, Qualitative Phytochemical Analysis and in Vitro Antibacterial Activity of Bauhinia tomentosa L. Journal of Natural Product and Plant Resources, 3, 31-36.

[30] Mir, A.M., Sawhney, S.S. and Jassal, M.M.S. (2013) Qualitative and Quantitative Analysis of Phytochemicals of Taraxacum officinale. Wudpecker Journal of Pharmacy and Pharmacology, 2, 1-5.

[31] Lucas, G.M. and Markakas, M. (1975) Phytic Acid and Other Phosphorus Compounds of Bean (Phaseolus vulgaris). Journal of Agricultural and Food Chemistry, 23, 13-15. http://dx.doi.org/10.1021/jf60197a016

[32] Ajai, A.I., Ochigbo, S.S., Jacob, J.O., Ndamitso, M.M. and Abubakar, U. (2012) Proximate and Mineral Compositions of Different Species of Kola Nuts. European Journal of Applied Engineering and Scientific Research, 1, 44-47.

[33] Odebunmi, E.O., Oluwaniyi, O.O., Awolola, G.V. and Adediji, O.D. (2009) Proximate and Nutritional Composition of Kola Nut (Cola nitida), Bitter Cola (Garcinia kola) and Alligator Pepper (Afromomum melegueta). African Journal of Biotechnology, 8, 308-310.

[34] Lowor, S.T., Aculey, P.C. and Assuah, M.K. (2010) Analysis of Some Quality Indicators in Cured Cola nitida (Vent). Agriculture and Biology Journal of North America, 1, 1206-1214.

[35] Guisseppe, R. and Baratta, T.M. (2000) Antioxidant Activity of Selected Essential Oil Components in Two Lipid Model Systems. African Journal of Biotechnology, 69, 167-174.

[36] Adeyeye, E. and Ayejuyo, O. (1994) Chemical Composition of Cola acuminata and Garcinia kola Seeds Grown in Nigeria. International Journal of Food Sciences and Nutrition, 45, 223-230. http://dx.doi.org/10.3109/09637489409166162

[37] Arogba, S.S. (2000) Comparative Analyses of the Moisture Isotherms, Proximate Compositions, Physical and Functional Properties of Dried Cola nitida and Garcinia kola Kernels. Journal of Food Compound Analysis, 13, 139-148. http://dx.doi.org/10.1006/jfca.1999.0839

[38] Durand, J.L. (2007) Les effets du déficit hydrique sur la plante: Aspects physiologiques. Fourrages, 190, 181-195.

[39] Lemaire, G., Charrier, X. and Hébert, Y. (1996) Nitrogen Uptake Capacities of Maize and Sorghum Crops in Different Nitrogen and Water Supply Conditions. Agronomies, 16, 231-246. http://dx.doi.org/10.1051/agro:19960403

[40] Voet, D.J., Voet, J.G. and Pratt, C.W. (2008) The Principles of Biochemistry. John Wiley \& Sons, Hoboken, 74-219.

[41] Agbeniyi, S.O. and Ayodele, M.S. (2010) Effect of Storage Moulds on the Nutritional Quality of Kolanuts in Nigeria. Pakistan Journal of Nutrition, 9, 512-515. http://dx.doi.org/10.3923/pjn.2010.512.515

[42] Dicko, M.H., H. Gruppen, Voragen, A.G.J. and van Berkel, W.J.H. (2002) Comparison of Content in Phenolic Compounds, Polyphenol Oxidase and Peroxidase in Grains of Fifty Sorghum Varieties from Burkina Faso. Journal of Agricultural and Food Chemistry, 50, 3780-3788. http://dx.doi.org/10.1021/jf0116420

[43] Moosmann, B. and Behl, C. (1999) The Antioxidant Neuroprotective Effects of Estrogens and Phenolic Compounds Are Independent from Their Estrogenic. Proceedings of the National Academy of Sciences of the United States of America, 96, 8867-8872. http://dx.doi.org/10.1073/pnas.96.16.8867

[44] Parr, A.J. and Bolwell, G.P. (2000) Phenols in the Plant and in Man. The Potential for Possible Nutritional Enhancement of the Diet by Modifying the Phenols Content or Profile. Journal of Science Food and Agriculture, 80, 985-1012. http://dx.doi.org/10.1002/(SICI)1097-0010(20000515)80:7<985::AID-JSFA572>3.0.CO;2-7

[45] Santos-Buelga, C. and Scalbert, A. (2000) Proanthocyanidins and Tannin-Like Compounds: Nature, Occurrence, Dietary Intake and Effects on Nutrition and Health. Journal of Science Food and Agriculture, 80, 1094-1117. http://dx.doi.org/10.1002/(SICI)1097-0010(20000515)80:7<1094::AID-JSFA569>3.0.CO;2-1

[46] Ferreira, D. and Slade, D. (2002) Oligomeric Proanthocyanidins: Naturally Occurring O-Heterocycles. Natural Product Reports, 19, 517-541. http://dx.doi.org/10.1039/b008741f

[47] Terashima, K., Takaya, Y. and Niwa, M. (2002) Powerful Antioxidative Agents Based on Garcinoic Acid from Garci- 
nia kola. Bioorganic \& Medicinal Chemistry, 10, 1619-1625. http://dx.doi.org/10.1016/S0968-0896(01)00428-X

[48] Middleton, E.J., Kandaswani, C. and Theoharides, T.C. (2000) The Effects of Plant Flavonoids on Mammalian Cells, Implication for Inflammation, Heart Disease and Cancer. Pharmacology, 52, 673-751.

[49] Ajayi, L.A., Dawodu, F.A. and Oderinde, R.A. (2003) Fatty Acid Composition and Metal Content of Adansonia digitata Seeds and Seed Oil. La Rivisita Italiana Delle Sosteanze Grasse, 80, 41-43.

[50] Nelson, D.L. and Cox, M.M. (2008) Lehninger Principles of Biochemistry. W. H. Freeman and Company, New York, 342-343.

[51] Meuunier, N., O’Connor, J.M., Maiani, G., Cashman, K.D., Secker, D.L. and Ferry, M. (2005) Importance of Zinc in the Elderly: The ZENITH Study. European Journal of Clinical Nutrition, 59, S1-S4. http://dx.doi.org/10.1038/sj.ejcn.1602286

[52] Frederickson, C.J., Suh, S.W., Silva, D., Frederickson, C.J. and Thompson, R.B. (2000) Importance of Zinc in the Central Nervous System: The Zinc Containing Neuron. Journal of Nutrition, 130, 1471-1483.

[53] Atanda, O.O., Olutayo, A., Mokwunye, F.C., Oyebanji, A.O. and Adegunwa, M.O. (2011) The Quality of Nigerian Kola Nuts. African Journal of Food Science, 5, 904-909.

[54] Abbaspour, N., Hurrell, R. and Kelishadi, R. (2014) Review on Iron and Its Importance for Human Health. Journal of Research in Medical Sciences, 19, 164-174.

[55] McDowell, L.R. (2003) Minerals in Animal and Human Nutrition. Elsevier Science, Amsterdam.

[56] Hollander, D.I., Nagey, D.A. and Pupkin, M.J. (1987) Magnesium Sulfate and Ritodrine Hydrochloride: A Randomized Comparison. American Journal of Obstetrics and Gynecology, 156, 631-637. http://dx.doi.org/10.1016/0002-9378(87)90066-4

[57] Feillet-Coudray, C., Coudray, C., Gueux, E., Mazur, A. and Rayssiquier, Y. (2003) A New in Vitro Blood Load Test Using a Magnesium Stable Isotope for Assessment of Magnesium Status. Journal of Nutrition, 133, 1220-1223.

[58] Gnaglom, E. (2012) Le baobab et ses effets. Nutra News Science, Nutrition, Prévention et Santé. www.africa1.com/spip.php?article26071

[59] Eleyinmi, A.F., Bressler, D.C., Amoo, I.A., Sporns, P. and Oshodi, A.A. (2006) Chemical Composition of Bitter Cola (Garcinia kola) Seed and Hulls. Polish Journal of Food and Nutrition Sciences, 56, 395-400.

[60] Adeyeye, E., Asaolu, S. and Aluko, A. (2007) Amino Acid Composition of Two Masticatory Nuts (Cola acuminata and Garcinia kola) and a Snack Nut (Anacardium occidentale). International Journal of Food Sciences and Nutrition, 58, 241-249. http://dx.doi.org/10.1080/09637480701486108

[61] Kumar, R. (1991) Anti-Nutritional Factors, the Potential Risks of Toxicity and Methods to Alleviate Them. In: Speedy, A. and Pugliese, P.-C., Eds., Legume Trees and Other Fodder Trees as Protein Sources for Livestock, FAO Corporate Document Repository, Kuala Lumpur, Malaysia, 145-160.

[62] Shqueir, A.A., Brown, D.L., Taylor, S.J., Rivkin, I. and Klasing, K.C. (1989) Effects of Solvent Extraction, Heat Treatments and Added Cholesterol on Sesbania sesban Toxicity in Growing Chicks. Animal Feed Science and Technology, 27, 127-135. http://dx.doi.org/10.1016/0377-8401(89)90137-5

[63] Johnson, I.T., Gee, J.M., Price, K., Curl, C. and Fenwick, G.R. (1986) Influence of Saponin on Gut Permeability and Active Nutrient Transport in Vitro. Journal of Nutrition, 116, 2270-2277.

[64] Pant, G., Panwaar, M.S., Negi, D.S. and Rawat, M.S. (1988) Spermicidal Activity and Chemical Analysis of Pentapanax leschenaultii. Medica Planta, 54, 476-477.

[65] Kumar, R. and Sing, M. (1984) Tannins: Their Adverse Role in Ruminant Nutrition. Journal of Agriculture and Food Chemistry, 32, 447-453. http://dx.doi.org/10.1021/jf00123a006

[66] Barry, T.N. (1987) Secondary Compounds of Forages. In: Hacker, J.B. and Ternouth, J.H., Eds., Nutrition of Herbivores, Academic Press, Sydney, 91-120.

[67] Soetan, K.O. and Oyewole, O.E. (2009) The Need for Adequate Processing to Reduce the Antinutritional Factors in Plants Used as Human Foods and Animal Feeds: A Review. African Journal of Food Science, 3, 223-232. 